\title{
KONTRIBUSI USAHA JAJANAN KUE TERHADAP PENDAPATAN RUMAH TANGGA DI DESA NAIN KECAMATAN WORI KABUPATEN MINAHASA UTARA
}

\author{
Daniel Koibur \\ Gene H. M. Kapantow \\ Leonardus R. Rengkung
}

\begin{abstract}
This study aims to see how big the level of business benefits of snack cake and its contribution to household income. This research was conducted in October until December 2016. The data used are primary data and secondary data. This research was conducted by direct interview technique with 15 (fifteen) respondents in this case cake snack businessman and also using written data in document form obtained from village head. The data obtained were analyzed using descriptive analysis and presented in tabular form. The results of this study indicate that the average cake snack profit is Rp.4.503.835 in 1 (one) month, while the contribution of cake snack business to household income has a percentage of $83.65 \%$ in 1 (one) month.
\end{abstract}

Keywords: contributions, household income, Nain Village, Wori Sub-district, North Minahasa District.

\begin{abstract}
ABSTRAK
Penelitian ini bertujuan untuk melihat seberapa besar tingkat keuntungan usaha jajanan kue dan kontribusinya terhadap pendapatan rumah tangga. Penelitian ini dilaksanakan pada bulan Oktober hingga Desember 2016. Data yang digunakan adalah data primer dan data sekunder. Penelitian ini dilakukan dengan teknik wawancara langsung dengan 15 (lima belas) orang responden dalam hal ini pengusaha jajanan kue dan juga menggunakan data tertulis dalam bentuk dokumen yang diperoleh dari kepala desa. Data yang diperoleh dianalisis mengunakan analisis deskriptif dan disajikan dalam bentuk tabel. Hasil penelitian ini menunjukkan bahwa rata-rata keuntungan jajanan kue adalah sebesar Rp.4.503.835 dalam 1 (satu) bulan, sedangkan kontribusi usaha jajanan kue terhadap pendapatan rumah tangga memiliki persentase sebesar $83,65 \%$ dalam 1 (satu) bulan.
\end{abstract}

Kata kunci: kontribusi, pendapatan rumah tangga, Desa Nain, Kecamatan Wori, Kabupaten Minahasa Utara.

\section{PENDAHULUAN}

\section{Latar Belakang}

Sektor pertanian dan sektor industri merupakan dua sektor yang memegang peranan penting dalam perekonomian Indonesia. Pertanian yang merupakan sektor primer dalam suatu perekonomian, pengembangan dan pembangunanya harus dilakukan secara matang sejalan dengan pengembangan sektor industri dan jasa yang menjadi pendukung sehingga tidak terjadi kepincangan dalam perekonomian (Sumampouw, 2015).

UU No. 5 Tahun 1984 menyatakan bahwa Industri adalah kegiatan ekonomi yang 
mengolah bahan mentah, bahan baku, barang setengah jadi, dan barang jadi menjadi barang dengan nilai yang lebih tinggi untuk penggunaannya, termasuk perekayasaan industri (Sasrawan, 2014 dalam Gobel, 2015).

UKM merupakan suatu bentuk usaha kecil masyarakat yang pendiriannya berdasarkan inisiatif seseorang. UKM dapat menyerap banyak tenaga kerja Indonesia yang masih menganggur. UKM juga memanfatkan berbagai Sumber Daya Alam yang berpotensial di suatu daerah yang belum diolah secara komersial (Kristiyanti, 2012).

Industri Rumah Tangga Pangan (IRTP) adalah industri yang mengolah pangan yang bertempat di rumah tempat tinggal dengan peralatan manual hingga semi otomatis (Badan Pengawas Obat dan Makanan, 2003 dalam Sumampouw, 2015).

Makanan jajanan sudah menjadi bagian yang tidak terpisahkan dari kehidupan masyarakat, baik di perkotaan maupun pedesaan. Makanan jajanan atau street food adalah jenis makanan yang dijual di kaki lima, pinggiran jalan, di stasiun, di pasar, tempat pemukiman serta lokasi yang sejenis. Makanan jajanan banyak sekali jenisnya dan sangat bervariasi dalam bentuk, keperluan dan harga (Winarto, 1997 dalam Mudjajanto dan Purwati, 2003).

Jenis pekerjaan masyarakat di Desa Nain berbeda-beda, tetapi pada umumnya masyarakat Desa Nain berprofesi sebagai nelayan. Selain nelayan, masyarakat Desa Nain juga memiliki beberapa jenis pekerjaan di antaranya; pedagang kue, warung, guru, swasta, MRT, tukang/buru, karyawan, dan lainnya.

Usaha kecil dan menengah di Desa Nain merupakan inisiatif dari masyarakat, oleh kerena itu modal serta manajemennya diatur oleh rumah tangga itu sendiri. Usaha jajanan kue banyak dijumpai dan juga diminati masyarakat karena harganya yang dapat dijangkau oleh semua kalangan, mulai dari kalangan bawah, menengah, hingga kalangan atas. Umumnya penjualan kue yang paling banyak adalah penjualan kue basah.
Kue basah merupakan usaha jajanan kue yang setiap harinya dijual karena banyak diminati oleh masyarakat dan juga dapat menjadi bekal bagi para pelaut atau nelayan untuk dibawah pergi melaut dengan waktu melaut para nelayan yang berbeda-beda. Rata-rata penjualan kue basah atau jajanan kue yang ada di Desa Nain dijual dengan harga yang murah yaitu Rp.1.000. Sedangkan harga jual jajanan kue di Manado jauh lebih mahal dibandingkan dengan harga jual yang ada di Desa Nain. Pemesanan dan penjualan kue di Manado rata-rata yaitu Rp.1.500 hingga Rp.2.000.

Walaupun sebagian besar bahan dasar pembuatan kue didatangkan dari Manado, namun harga jual jajanan kue di Desa Nain jauh lebih murah dari harga jual kue yang sama di Manado. Fakta ini menimbulkan pertanyaan mengenai besarnya keuntungan yang didapat oleh usaha jajanan kue di Desa Nain dan seberapa besar kontribusi usaha ini terhadap pendapatan rumah tangga di Desa Nain.

\section{Rumusan Masalah}

Berdasarkan latar belakang diatas, maka yang menjadi rumusan masalah dalam penelitian ini adalah berapa besar keuntungan usaha jajanan kue dan kontribusinya terhadap pendapatan rumah tangga yang ada di Desa Nain.

\section{Tujuan Penelitian}

Tujuan dari penelitian ini adalah untuk melihat seberapa besar tingkat keuntungan usaha jajanan kue dan kontribusinya terhadap pendapatan rumah tangga di Desa Nain Kecamatan Wori Kabupaten Minahasa Utara.

\section{Manfaat Penelitian \\ Penelitian ini diharapkan dapat} bermanfaat bagi:

1. Masyarakat

Menambahkan pengetahuan kepada masyarakat khususnya para pelaku usaha, agar dapat memahami kontribusi usaha jajanan kue terhadap pendapatan rumah tangga. 
2. Penulis

Selain untuk penyelesaian studi akhir, juga dapat menambahkan pemahaman dan pengetahuan kepada penulis tentang bagaimana cara menganalisis suatu usaha serta melihat seberapa besar kontribusi dari usaha tersebut terhadap pendapatan rumah tangga pengusaha.

\section{METODOLOGI PENELITIAN}

\section{Waktu dan Tempat Penelitian}

Penelitian ini berlangsung selama 3 bulan sejak bulan Oktober sampai bulan Desember 2016. Tempat penelitian di Desa Nain Kecamatan Wori Kabupaten Minahasa Utara.

\section{Metode Pengumpulan Data}

Data yang digunakan dalam penelitian ini adalah data primer dan data sekunder. Data primer merupakan data yang diperoleh dari lapangan tempat penelitian dalam hal ini adalah para pelaku atau pengusaha jajanan kue dengan data-data sebagai berikut; jumlah produksi, harga jual, dan biaya-biaya. Data primer ini ditanyakan langsung pada para pelaku usaha jajanan kue, untuk kepentingan peneliti dan data tersebut belum pernah dipublikasikan sebelumnya. Data primer ini diperoleh dengan cara survei dan wawancaara langsung.

Data sekunder diperoleh dari instansi dan kepala desa mengenai data yang diperlukan dalam penelitian ini yaitu seperti data tentang jumlah penduduk, data jenis pekerjaan dan lainya.

\section{Metode Pengambilan Sampel}

Objek dalam penelitian ini adalah masyarakat Desa Nain yang mengusahakan jajanan kue. Pengusaha jajanan kue yang berada di Desa Nain berjumlah 48 pengusaha. Namun dari 48 pengusaha jajanan kue ini terdapat 15 pengusaha yang secara rutin membuat dan menjual kue sedangkan 33 pengusaha lainnya hanya membuat kue berdasarkan pesanan atau ketersediaan modal. Pengambilan sampel dalam penelitian ini dilakukan secara sengaja (purposive sampling), yaitu hanya 15 pengusaha jajanan kue yang secara rutin menproduksi dan menjual kue.

\section{Konsepsi Pengukuran Variabel}

Variabel yang diukur dalam penelitian ini adalah:

1. Keuntungan, yaitu sejumlah uang yang diterima setelah hasil penjualan dikurangi dengan biaya-biaya yang dikeluarkan (Rp/bulan). Sedangkan untuk mencari keuntungan usaha jajanan kue itu sendiri, terdapat beberapa tahapan yang dilihat terlebih dahulu yaitu:

a. Produksi, yaitu proses produksi yang dilakukan oleh pengusaha jajanan kue dalam setiap kali proses produksi (buah/bulan).

b. Harga jual, adalah target atau capaian harga yang diberikan dari pengusaha jajanan kue kepada para konsumen atau pembeli $(\mathrm{Rp})$.

c. Biaya produksi, yaitu biaya-biaya yang dikeluarkan untuk setiap kali proses produksi jajanan kue dilakukan, seperti biaya-biaya varibel (Rp/bulan).

d. Penerimaan, yaitu jumlah uang yang diterima pengusaha jajanan kue sebelum dikurangi dengan total biaya yang dikeluarkan ( $\mathrm{Rp} / \mathrm{bulan}$ ).

2. Pendapatan rumah tangga, yaitu semua jumlah pendapatan dari setiap anggota keluarga yang sudah bekerja dalam suatu rumah tangga (Rp/bulan).

\section{Metode Analisis Data}

Data yang diperoleh dalam penelitian ini dianalisis dengan menggunakan analisis deskriptif dan disajikan dalam bentuk tabel. Sedangkan untuk mengetahui keuntungan dari pengusaha jajanan kue yang berada di Desa Nain, menggunakan analisis keuntungan dengan: 


\author{
Rumus: \\ $\boldsymbol{\pi}=\mathbf{T R}-\mathbf{T C}$ \\ Dimana : \\ $\pi=$ Profit (Keuntungan) \\ $\mathrm{TR}=$ Total Revenue $($ Penerimaan $)$ \\ $\mathrm{TC}=$ Total Cost $($ Biaya) \\ Perhitungan untuk menentukan jumlah \\ penerimaan usaha jajanan kue dapat dihitung \\ dengan menggunakan:
}

Rumus:

$\mathbf{T R}=\mathbf{Q} \times \mathbf{P}$

Dimana :

$\mathrm{TR}=$ Total revenue/total penerimaan.

$\mathrm{Q}=$ Quantity/jumlah produk jajanan kue yang terjual tiap hari.

$\mathrm{P}=$ Price/harga jajanan kue.

Sedangkan perhitungan kontribusi usaha jajanan kue terhadap pendapatan rumah tangga menggunakan:

Rumus:

$$
\text { Kontribusi }=\frac{\text { Pendapatan usaha atau pekerjaan }}{\text { Total pendapatan rumah tangga }} 100 \%
$$

\section{HASIL DAN PEMBAHASAN}

\section{Deskripsi Daerah Penelitian}

\section{Letak Wilayah}

Desa Nain merupakan salah satu desa dari 3 desa yaitu Desa Nain Satu (Nain-Siau), Nain (Nain-Bajo), dan Desa Tampi-Tarente yang berada di pulau Nain dan terletak di Kecamatan Wori Kabupaten Minahasa Utara. Secara umum, Desa Nain memiliki luas lahan 540 ha dengan memiliki 13 jaga. Adapun batas-batas wilayah di Desa Nain adalah sebagai berikut :

a. Sebelah utara berbatasan dengan Desa Tatampi-Tarente

b. Sebelah selatan berbatasan dengan Desa Nain Satu (Siau)

c. Sebelah barat berbatasan dengan Laut Sulawesi

d. Sebelah timur berbatasan dengan Laut Sulawesi

\section{Kondisi Demografi}

a. Demografi Penduduk

Secara demografis jumlah kepala keluarga di Desa Nain adalah 644 KK yang terdiri dari 2.089 jiwa.

b. Penduduk Menurut Jenis Kelamin

Berdasarkan rekapitulasi, penduduk Desa Nain berjumlah 2.089 jiwa, yang terdiri dari laki-laki 1.077 jiwa dan perempuan 1.012 jiwa.

Tabel 1. Jumlah Penduduk Berdasarkan Jenis Kelamin

\begin{tabular}{lcc}
\hline Jenis Kelamin & $\begin{array}{c}\text { Jumlah } \\
\text { (Jiwa) }\end{array}$ & $\begin{array}{c}\text { Persentase } \\
(\%)\end{array}$ \\
\hline Laki-laki & 1.077 & 51.56 \\
Perempuan & 1.012 & 48.44 \\
\hline Jumlah & 2.089 & 100 \\
\hline Sumber:
\end{tabular}

Sumber: Data Statistik Desa Nain, 2016

\section{Sarana dan Prasarana}

Sarana dan prasarana merupakan dua hal yang tidak dapat dipisahkan karena keduanya saling mengisi atau melengkapi. Sarana dan prasarana yang ada di Desa Nain

\begin{tabular}{|c|c|}
\hline Sarana dan Prasarana & Jumlah \\
\hline \multicolumn{2}{|l|}{ Prasarana pendidikan } \\
\hline$-\quad$ TK & 1 buah \\
\hline$-\quad S D$ & 2 buah \\
\hline - SMP & 1 buah \\
\hline - $\quad$ MTs & 1 buah \\
\hline - $\quad$ SMK & 1 buah \\
\hline - MA & 1 buah \\
\hline Prasarana kesehatan & 1 buah \\
\hline \multicolumn{2}{|l|}{ Prasarana peribadatan } \\
\hline - Masjid & 1 buah \\
\hline \multicolumn{2}{|l|}{ Prasarana air bersih } \\
\hline - Sumur desa & 2 buah \\
\hline \multicolumn{2}{|l|}{ Sarana transportasi } \\
\hline - $\quad$ Perahu fiber & 125 buah \\
\hline - Perahu taksi laut & 4 buah \\
\hline - $\quad$ Perahu katinting & 75 buah \\
\hline \multicolumn{2}{|l|}{ Prasarana perdagangan } \\
\hline - Warung & 32 buah \\
\hline - Lainnya & 24 buah \\
\hline
\end{tabular}
dapat dilihat pada Tabel 2 :

\section{Tabel 2. Sarana dan Prasarana}

Sumber: Data Statistik Desa Nain, 2016 
Mata Pencaharian Masyarakat Desa Nain Penduduk Desa Nain memiliki mata pencaharian yang berbeda-beda yaitu sebagai: Petani, Nelayan, Tukang, TNI/POLRI, POL PP, Pegawai Negeri Sipil, Wiraswasta, dan Mengurus Rumah Tangga. Jenis mata pencaharian penduduk secara rinci dapat dilihat pada Tabel 3 .

\begin{tabular}{|c|c|c|}
\hline \multirow[t]{2}{*}{ Tabel 3.} & \multirow{2}{*}{$\begin{array}{l}\text { Jenis Mata } \\
\text { Masyarakat } \\
\text { Tahun } 2016\end{array}$} & Pencaharian \\
\hline & & Desa Nain \\
\hline $\begin{array}{c}\text { Jenis } \\
\text { Mata Pencaharian }\end{array}$ & $\begin{array}{l}\text { Jumlah } \\
\text { (Orang) }\end{array}$ & $\begin{array}{c}\text { Persentase } \\
(\%)\end{array}$ \\
\hline Petani & 3 & 0,24 \\
\hline Nelayan & 648 & 51,22 \\
\hline Tukang & 11 & 0,87 \\
\hline TNI/POLRI & 2 & 0,16 \\
\hline POL PP & 1 & 0,08 \\
\hline $\begin{array}{l}\text { Pegawai Negeri } \\
\text { Sipil }\end{array}$ & 2 & 0,16 \\
\hline Wiraswasta & 32 & 2,53 \\
\hline $\begin{array}{l}\text { Mengurus Rumah } \\
\text { Tangga (MRT) }\end{array}$ & 566 & 44,74 \\
\hline Jumlah & 1.265 & 100 \\
\hline
\end{tabular}

Sumber: Data Statistik Desa Nain, 2016

Tabel 3 menunjukkan jenis mata pencaharian penduduk Desa Nain dengan persentase masing-masing jenis mata pencaharian. Dari Tabel 3 dapat dilihat bahwa jumlah mata pencaharian sebagai Nelayan adalah yang paling banyak dengan jumlah 648 orang dengan persentase $51.22 \%$.

\section{Karakteristik Responden}

\section{Umur Responden}

Umur merupakan salah satu faktor yang mempengaruhi perilaku dalam melakukan atau mengambil keputusan dan dapat bekerja secara optimal serta produktif. Seiring dengan perkembangan waktu, umur manusia akan mengalami perubahan dalam hal ini penambahan usia yang dapat mengakibatkan turunnya tingkat produktifitas seseorang dalam bekerja (Gusmaniar, 2013).
Tabel 4. Jumlah Responden Menurut Golongan Umur

\begin{tabular}{ccc}
\hline Umur (Tahun) & $\begin{array}{c}\text { Jumlah } \\
\text { (Responden) }\end{array}$ & $\begin{array}{c}\text { Persentase } \\
(\%)\end{array}$ \\
\hline$\leq 40$ & 2 & 13,33 \\
$41-50$ & 1 & 6,67 \\
$51-60$ & 3 & 20,00 \\
$61-70$ & 5 & 33,33 \\
$71-80$ & 4 & 26,67 \\
\hline Jumlah & 15 & 100 \\
\hline
\end{tabular}

Hasil persentase umur responden pada Tabel 4 menjelaskan bahwa, umur dalam penelitian ini tidak berpengaruh terhadap pengusaha jajanan kue karena semakin tua umur responden maka semakin berpengalaman. Selain itu, faktor yang membuat umur tidak berpengaruh terhadap pengusaha jajanan kue ialah tanggungan yang menjadi tanggung jawab responden sehingga membuat mereka harus bekerja keras untuk menghidupi setiap tanggungan mereka.

\section{Tingkat Pendidikan Responden}

Pendidikan merupakan hal yang sangat penting di dalam kehidupan manusia dan pendidikan itu sendiri akan diperoleh setiap orang secara formal maupun non formal.

Tabel 5. Jumlah Responden Berdasarkan Tingkat Pendidikan Deskripsi

\begin{tabular}{lcc}
\hline $\begin{array}{c}\text { Tingkat } \\
\text { Pendidikan }\end{array}$ & $\begin{array}{c}\text { Jumlah } \\
\text { (Orang) }\end{array}$ & $\begin{array}{c}\text { Persentase } \\
(\%)\end{array}$ \\
\hline Tidak Tamat SD & 12 & 80,00 \\
Tamat SD & 2 & 13,33 \\
Tamat SMP & 1 & 6,67 \\
\hline Jumlah & 15 & 100 \\
\hline
\end{tabular}

Hasil wawancara yang dilakukan terhadap 15 responden yang ada di Desa Nain pada Tabel 5, menjelaskan bahwa rata-rata pendidikan pengusaha jajanan kue adalah tidak tamat SD yang berjumlah 12 orang dengan persentase $80 \%$ dan merupakan 
jumlah terbanyak. Pengusaha jajanan kue yang tamat SD hanya berjumlah 2 orang dengan persentase $13,33 \%$ sedangkan tamatan SMP merupakan jumlah yang paling sedikit yaitu 1 orang dengan persentase $6,67 \%$.

\section{Jumlah Tanggungan Responden}

Jumlah tanggungan yang dimaksudkan dalam penelitian ini adalah anggota keluarga yang statusnya belum berkeluarga (single) dan masih di tanggung atau bergantung pada responden. Jumlah anggota keluarga yang ditanggung oleh responden dapat dilihat pada Tabel 6.

\begin{tabular}{ccc} 
Tabel 6. & $\begin{array}{c}\text { Jumlah } \\
\text { Responden }\end{array}$ & Tanggungan \\
\hline $\begin{array}{c}\text { Jumlah } \\
\text { Tanggungan } \\
\text { (Orang) }\end{array}$ & $\begin{array}{c}\text { Jumlah } \\
\text { (Responden) }\end{array}$ & $\begin{array}{c}\text { Persentase } \\
(\%)\end{array}$ \\
$\leq 3$ & 12 & 80,00 \\
$\geq 6$ & 3 & 20,00 \\
\hline Total & 15 & 100 \\
\hline
\end{tabular}

Tabel 6 menunjukan jumlah tanggungan keluarga pengusaha jajanan kue terbanyak adalah pada responden yang berjumlah 3 orang dengan jumlah tanggungan $\geq 6$ orang dengan persentase $20,00 \%$. Sedangkan jumlah responden yang terbanyak yaitu 12 orang dengan persentase $80 \%$ memiliki jumlah tanggungan $\leq 3$ orang.

\section{Deskripsi Usaha Jajanan Kue}

Hasil penelitian ini menunjukkan bahwa usaha jajanan kue di Desa Nain merupakan usaha yang dikelolah oleh masyarakat sediri. Usaha jajanan kue yang diproduksi oleh pengusaha jajanan kue bukan hannya satu jenis kue melainkan ada beberapa jenis kue.

Jenis jajanan kue di Desa Nain berjumlah 13 jenis jajanan kue yaitu: panada terigu, biapong kukus, biapong goreng, brot goreng, pisang goreng, nogo sari, lalampa, balapis, talam, binyolos kacang hijau, cucur, pia dan martabak. Kue yang paling banyak di produksi adalah panada terigu dengan jumlah
29.100 buah dalam 1 bulan, sedangkan jumlah produksi jajanan kue yang paling sediki adalah martabak yaitu 3.600 buah dalam 1 bulan.

\section{Produksi Usaha Jajanan Kue}

Produksi jajanan kue adalah proses pembuatan kue yang dilakukan oleh pengusaha jajanan kue dalam satu kali produksi. Umumnya proses produksi jajanan kue dilakukan setiap harinya mulai dari hari senin hingga hari minggu. Proses produksi jajanan kue yang paling banyak adalah pada waktu pagi dan sore hari. Produksi usaha jajanan kue dapat dilihat pada Tabel 7.

\section{Tabel 7. Produksi Jajanan Kue dalam 1} Bulan

\begin{tabular}{ccc}
\hline $\begin{array}{c}\text { Skala Produksi Kue } \\
\text { (Buah/Bulan) }\end{array}$ & $\begin{array}{c}\text { Jumlah } \\
\text { (Responden) }\end{array}$ & $\begin{array}{c}\text { Persentase } \\
(\%)\end{array}$ \\
\hline$\leq 9.000$ & 4 & 26,67 \\
$9.001-13.000$ & 6 & 40,00 \\
$13.001-17.000$ & 2 & 13,33 \\
$17.001-21.000$ & 2 & 13,33 \\
$\geq 21.000$ & 1 & 6,67 \\
\hline Jumlah & 15 & 100 \\
\hline
\end{tabular}

Tabel 7 menunjukkan skala dan persentase dari produksi usaha jajanan kue dalam 1 bulan. Persentase terbesar adalah $40,00 \%$ memiliki jumlah responden 6 orang dengan skala produksi yang dihasilkan berkisar antara $9.001-13.000$ (buah) jajanan kue. Sedangkan skala produksi kue $\geq 21.000$ merupakan persentase terkecil yaitu $6,67 \%$ dengan jumlah responden 1 orang.

\section{Penjualan Jajanan Kue}

Penelitian ini menunjukkan bahwa proses penjualan jajanan kue di Desa Nain adalah proses penjualan secara langsung tanpa melalui perantara atau penitipan. Penjualan jajanan kue bukan hanya dijual di Desa Nain saja melainkan dijual juga ke Desa Tampi-Tarente. Proses pendistribusian jajanan kue dilakukan dengan 2 cara. Pertama konsumen dapat melakukan pembelian secara 
langsung di tempat produksi pembuatan kue. Kedua pengusaha jajanan kue menyewa orang untuk melakukan penjualan. Penjualan yang dilakukan penjual adalah berjualan mengelilingi Desa Nain dan ada juga yang berjualan ke Desa Tampi-Tarente. Proses pembayaran yang dilakukan oleh pengusaha jajanan kue kepada penjual yaitu dengan pembagian $20 \%$ dari hasil penerimaan diberikan kepada penjual dengan tambahan beberapa kue.

\section{Biaya Variabel dan Biaya Tetap}

\section{a. Biaya Variabel}

Biaya variabel yang dikeluarkan oleh pengusaha jajanan kue di Desa Nain pada waktu proses produksi dilakukan dalam 1 bulan berbeda-beda. Biaya-biaya yang termasuk didalam biaya variabel adalah biaya bahan baku pembuatan kue, biaya bahan bakar dan biaya tenaga kerja.

b. Biaya Tetap

Biaya tetap adalah biaya-biaya yang dikeluarkan pada waktu memulai sebuah usaha baru. Biaya ini dikeluarkan untuk pembelian peralatan produksi yang akan digunakan pada jangka waktu yang lama. Peralatan produksi dalam penelitian ini mengalami penyusutan karena pemakaiannya terhadap produksi jajanan kue.

Tabel 8 menunjukkan bahwa 15 pengusaha jajanan kue yang menjadi responden memiliki jumlah biaya yang berbeda-beda. Rata-rata jumlah biaya variabel dari 15 responden dalam 1 bulan adalah Rp.8.355.900 sedangkan rata-rata biaya tetap adalah Rp.265.

Tabel 8. Biaya Variabel dan Biaya Tetap

\begin{tabular}{cccc}
\multicolumn{4}{c}{ Jajanan Kue } \\
$\begin{array}{c}\text { Skala Produksi Kue } \\
\text { (Buah/Bulan) }\end{array}$ & $\begin{array}{c}\text { Jumlah } \\
\text { (Responde) }\end{array}$ & $\begin{array}{c}\text { Biaya } \\
\text { Variabel } \\
\text { (Bulan/Rp) }\end{array}$ & $\begin{array}{c}\text { Biaya } \\
\text { Tetap } \\
\text { (Rp) }\end{array}$ \\
\hline$\leq 9.000$ & 4 & 21.285 .000 & 1.023 \\
$9.001-13.000$ & 6 & 47.976 .000 & 1.543 \\
$13.001-17.000$ & 2 & 24.202 .500 & 299 \\
$17.001-21.000$ & 2 & 15.705 .000 & 903 \\
$\geq 21.000$ & 1 & 16.170 .000 & 213 \\
\hline Total & 15 & 125.338 .500 & 3.981 \\
\hline Rata-rata & & 8.355 .900 & 265 \\
\hline
\end{tabular}

\section{Pendapatan Responden Pendapatan Jajanan Kue}

Tinggi rendahnya pendapatan suatu usaha tergantung pada seberapa besar jumlah produksi yang dihasilkan, harga jual barang tersebut dan semua biaya produksi yang dikeluarkan selama proses produksi dilakukan. Pengusaha jajanan kue yang ada di Desa Nain adalah para ibu-ibu rumah tangga bahkan ada juga ibu-ibu janda. Usaha jajanan kue merupakan pekerjaan pokok yang dilakukan setiap harinya bagi para ibu-ibu yang ada di Desa Nain. Pendapatan pengusaha jajanan kue dapat dilihat pada Tabel 9.

Tabel 9. Pendapatan Pengusaha Jajanan Kue dalam 1 Bulan

\begin{tabular}{ccccc}
\hline $\begin{array}{c}\text { Skala Produksi } \\
\text { (Buah) }\end{array}$ & $\begin{array}{c}\text { Frekuensi } \\
\text { (Responden) }\end{array}$ & $\begin{array}{c}\text { Penerimaan } \\
\text { (Rp) }\end{array}$ & $\begin{array}{c}\text { Pengeluaran } \\
(\mathrm{Rp})\end{array}$ & $\begin{array}{c}\text { Pendapatan } \\
\text { (Rp) }\end{array}$ \\
\hline$\leq 9.000$ & 4 & 32.700 .000 & 21.286 .023 & 11.413 .977 \\
$9.001-13.000$ & 6 & 66.900 .000 & 47.977 .543 & 18.922 .457 \\
$13.001-17.000$ & 2 & 32.850 .000 & 24.202 .799 & 8.647 .201 \\
$17.001-21.000$ & 2 & 37.200 .000 & 15.705 .903 & 21.494 .097 \\
$\geq 21.000$ & 1 & 23.250 .000 & 16.170 .213 & 7.079 .787 \\
\hline Total & 15 & 192.900 .000 & 125.342 .481 & 67.557 .519 \\
\hline Rata-rata & & 12.860 .000 & 8.356 .165 & 4.503 .835 \\
\hline
\end{tabular}

Tabel 9 menunjukkan bahwa penerimaan yang telah diperoleh responden dikurangi dengan biaya yang dikeluarkan maka rata-rata pendapatan yang diperoleh pengusaha jajanan kue dalam 1 bulan Rp.4.503.835.

\section{Pendapatan di Luar Usaha Jajanan Kue}

Pekerjaan selain usaha jajanan kue yang dilakukan oleh anggota keluarga responden ialah nelayan dan beberapa pekerjaan sampingan. Jumlah responden yang diambil tidak semua anggota keluarganya bekerja sebagai nelayan karena rata-rata responden telah berusia tua. Jenis mata pencaharian nelayan tebagi menjadi beberapa jenis pencaharian diantaranya; pencaharian ikan 
tuna, ikan batu, ikan tongkol/deho, dan lainnya. Terdapat 4 orang nelayan (suami) dari 4 responden yang mata pencaharian sebagai nelayan dan memiliki 2 jenis pencaharian yaitu pencaharian ikan tuna dan ikan batu. Hasil dari wawancara terhadap penghasilan 4 orang nelayan ini rata-rata sama. Pendapatan nelayan serta pekerjaan sampingan dari responden dapat dilihat pada Tabel 10.

\begin{tabular}{lcc} 
Tabel 10. & $\begin{array}{c}\text { Pendapatan } \\
\text { Usaha } \\
\text { Bulan }\end{array}$ & $\begin{array}{c}\text { Keluarga Danan } \\
\text { Kue dalam 1 }\end{array}$ \\
\hline $\begin{array}{l}\text { Jenis } \\
\text { Pekerjaan }\end{array}$ & $\begin{array}{c}\text { Jumlah } \\
\text { (Orang) }\end{array}$ & $\begin{array}{c}\text { Total Pendapatan } \\
(\mathrm{Rp})\end{array}$ \\
\hline $\begin{array}{l}\text { Nelayan } \\
\text { Jual Baju } \\
\text { dan Ikan }\end{array}$ & 4 & 6.300 .000 \\
$\begin{array}{l}\text { Garam } \\
\begin{array}{l}\text { Warung } \\
\text { (kios) }\end{array}\end{array}$ & 1 & 900.000 \\
\hline
\end{tabular}

Pendapatan diluar usaha jajanan kue yang ada pada Tabel 10 menjelaskan bahwa 4 orang nelayan memiliki total pendapatan yaitu Rp.6.300.000. Sedangkan 2 orang responden memiliki pekerjaan sampingan yaitu responden pertama memiliki pekerjaan berjualan baju dan ikan garam dengan pendapatan dalam 1 bulan Rp.900.000. Responden kedua memiliki usaha warung dengan pendapatan Rp.6.000.000 dalam 1 bulan.

\section{Total Pendapatan Rumah Tangga}

Pendapatan rumah tangga diperoleh dari semua total pendapatan yang dihasilkan oleh anggota keluarga yang menjadi tanggunga responden dan telah bekerja. Rata-rata pendapatan rumah tangga dari 15 responden dalam penelitian ini adalah jumlah dari semua pendapatan yaitu pendapatan jajanan kue, nelayan, jual baju dan ikan garam serta warung (kios) yang diterima dalam kurun waktu 1 bulan dengan jumlah Rp.5.383.849. Rata-rata pendapatan rumah tangga pengusaha jajanan kue dapat dilihat pada Tabel 11.

Tabel 11. Distribusi Total Pendapatan Rumah Tangga Pengusaha Jajanan Kue dalam 1 Bulan

\begin{tabular}{lcc}
\hline $\begin{array}{c}\text { Skala Produksi } \\
\text { Kue (Buah) }\end{array}$ & $\begin{array}{c}\text { Jumlah } \\
\text { (Responden) }\end{array}$ & $\begin{array}{c}\text { Total } \\
\text { Pendapatan } \\
\text { Rumah } \\
\text { Tangga } \\
\text { (Rp) }\end{array}$ \\
\hline$\leq 9.000$ & 4 & 18.913 .977 \\
$9.001-13.000$ & 6 & 23.422 .457 \\
$13.001-17.000$ & 2 & 9.847 .201 \\
$17.001-21.000$ & 2 & 21.494 .097 \\
$\quad \geq 21.000$ & 1 & 7.080 .000 \\
\hline Total & 15 & 80.757 .732 \\
\hline Rata-rata & & 5.383 .849 \\
\hline
\end{tabular}

\section{Kontribusi Usaha Jajanan Kue Terhadap Pendapatan Rumah Tangga}

Kontribusi adalah sumbangan atau bagian, kontribusi usaha jajanan kue terhadap pendapatan keluarga adalah besarnya sumbangan atau pendapatan yang diperoleh dari usaha jajanan kue terhadap keseluruhan pendapatan dari pendapatan rumah tangga. Besarnya kontribusi usaha jajanan kue dapat dilihat pada Tabel 12.

Tabel 12. Kontribusi Pendapatan Usaha Jajanan Kue Terhadap Pendapatan Rumah Tangga dalam 1 Bulan

\begin{tabular}{lrc}
\hline \multicolumn{1}{c}{$\begin{array}{c}\text { Sumber } \\
\text { Pendapatan }\end{array}$} & $\begin{array}{c}\text { Jumlah } \\
\text { Pendapatan }\end{array}$ & $\begin{array}{c}\text { Kontribusi } \\
(\%)\end{array}$ \\
\hline Usaha Jajanan & 67.557 .519 & 83,65 \\
Kue & & \\
Nelayan & 6.300 .000 & 7,81 \\
Jual Baju dan & 900.000 & 1,11 \\
Ikan Garam & & \\
Warung & 6.000 .000 & 7,43 \\
\hline Total & 80.757 .519 & 100 \\
\hline Rata-rata & 5.383 .835 & \\
\hline
\end{tabular}


Berdasarkan Tabel 12 dapat dilihat bahwa kontribusi usaha jajanan kue terhadap total pendapatan rumah tangga adalah sebesar $83,65 \%$. Hal ini menunjukkan bahwa sebagian besar pendapatan rumah tangga berasal dari usaha jajanan kue. Usaha jajanan kue memberikan kontribusi lebih besar terhadap total pendapatan rumah tangga responden, pendapatan tersebut digunakan untuk memenuhi kebutuhan hidup keluarga, seperti biaya makan sehari-hari, dan lain sebagainya.

Kontribusi usaha jajanan kue terhadap pendapatan rumah tangga juga dapat dilihat berdasarkan rumusan kontribusi.

$$
\begin{aligned}
\text { Kontribusi Usaha Jajanan Kue } & =\frac{\text { Pendapatan usaha jajanan kue }}{\text { Total pendapatan rumah tangga }} 100 \% \\
\text { Kontribusi Usaha Jajanan Kue } & =\frac{67.557 .519}{80.757 .519} 100 \% \\
& =83,65 \%
\end{aligned}
$$

Berdasarkan rumusan kontribusi dapat dilihat bahwa kontribusi yang di hasilkan oleh usaha jajanan kue terhadap pendapatan rumah tangga yang ada di Desa Nain adalah $83,65 \%$ dalam 1 bulan.

\section{KESIMPULAN DAN SARAN}

\section{Kesimpulan}

Kesimpulan dari penelitian ini yang pertama adalah pengusaha jajanan kue memiliki keuntungan, dimana rata-rata penerimaan dari 15 responden yang diterima adalah Rp.12.860.000 dalam 1 bulan dikurangi dengan rata-rata biaya yang dikeluarkan sebesar Rp.8.356.165. Maka ratarata keuntungan yang diperoleh pengusaha jajanan kue adalah sebesar Rp.4.503.835 dalam 1 bulan. Kedua, usaha jajanan kue memberikan kontribusi yang cukup besar bagi pendapatan rumah tangga dengan persentase $83,65 \%$ dalam 1 bulan. Hal ini menunjukkan bahwa usaha jajanan kue merupakan pekerjaan pokok bagi para pengusaha jajanan kue yang ada di Desa Nain.

\section{Saran}

Berkaitan dengan penelitian ini, maka yang perlu diperhatikan dan harus dirubah adalah cara pandangan pengusaha jajanan kue mengenai untung rugi, biaya-biaya dan tenaga yang dikeluarkan oleh pengusaha agar dapat diperhitungkan dengan baik.

\section{DAFTAR PUSTAKA}

Gobel N. A. 2015. Analisis Keuntungan Usaha Sirup Segar CV. Segarindo Utama. Skripsi Fakultas Pertanian Unsrat. Ejournal Unsrat.ac.id. Diakses tanggal 1 September 2016.

Gusmaniar. 2013. Kontribusi Pendapatan Wanita Peternak Kelinci Terhadap Total Pendapatan Keluarga di Kelurahan Salokaraja Kecamatan Lalabata Kabupaten Soppeng. Skripsi

Fakultas Peternakan Universitas Hasanuddin Makasar. Repository. unhas.ac.id. Diakses tanggal 6 Desember 2016.

Kristiyanti M. 2012. Peran Strategis Usaha Kecil Menengah (UKM) dalam Pembangunan Nasional. Jurnal Majalah Ilmiah Informatika Vol. 3 No. 1, Januari 2012. Fakultas Ekonomi Universitas AKI. www.unaki.ac.id. Diakses tanggal 21 Oktober 2016.

Mudjajanto E. S dan Purwati. 2003. Aspek Gisi dan Keamanan Pangan Makanan Jajanan di Bursa Kue Subuh Pasar Senen, Jakarta Pusat. Jurnal Departemen GMSK Fakultas Pertanian IPB. Repository.ipb.ac.id. Diakses tanggal 22 Oktober 2016. 
Sumampouw N. N, O. Esry Laoh, dan Lyndon R. J. Pagemanan. 2015. Analisi Tingkat Keuntungan Usaha Rumah Tangga Kue Lumpia di Kelurahan Bumi Nyiur Kecamatan Wanea. Jurnal Volume 11 No 3A, November 2015:125-142. Fakultas Pertanian Unsrat. Ejournal Unsrat.ac.id. Diakses tanggal 1 September 2016. 